\title{
Possible involvement of IFNT in lymphangiogenesis in the corpus luteum during the maternal recognition period in the cow
}

\author{
Akane Nitta ${ }^{1}$, Koumei Shirasuna ${ }^{1}$, Shingo Haneda ${ }^{2}$, Motozumi Matsui ${ }^{2}$, Takashi Shimizu$^{1}$, \\ Shuichi Matsuyama ${ }^{3}$, Koji Kimura ${ }^{3}$, Heinrich Bollwein ${ }^{4}$ and Akio Miyamoto ${ }^{1}$ \\ ${ }^{1}$ Graduate School of Animal and Food Hygiene and ${ }^{2}$ Department of Clinical Veterinary Science, Obihiro University of \\ Agriculture and Veterinary Medicine, Obihiro 080-8555, Japan, ${ }^{3}$ National Institute of Livestock and Grassland \\ Science, Nasushiobara 305-0901, Japan and ${ }^{4}$ Clinic for Cattle, and Institute of Immunology, University of Veterinary \\ Medicine Hannover, 30173 Hannover, Germany \\ Correspondence should be addressed to K Shirasuna; Email: shirasuna@obihiro.ac.jp
}

\begin{abstract}
The corpus luteum (CL), which secretes large amounts of progesterone and is thus essential for establishing pregnancy, contains various types of immune cells that may play essential roles in CL function by generating immune responses. The lymphatic system is the second circulation system and is necessary for immune function, but the lymphatic system of the bovine $\mathrm{CL}$ has not been characterized in detail. We collected bovine CLs on days 12 and 16 of the estrous cycle (C12 and C16) and days 16 and 40 of early pregnancy (P16 and P40). Lymphatic endothelial hyaluronan receptor 1 (LYVE1) protein was detected in the CL by immunohistochemistry and western blotting and increased at P40 compared with C16. The mRNA expression levels of lymphangiogenic factors, such as vascular endothelial growth factor-C (VEGFC), VEGFD, and their common receptor VEGFR3, as well as the lymphatic endothelial cell (LyEC) marker podoplanin, increased in P16 and P40 CLs. Thus, it is suggested that the lymphatic system of the bovine CL reconstitutes during early pregnancy. Interferon tau (IFNT) from the conceptus in the uterus is a candidate for activating luteal lymphangiogenesis during the maternal recognition period (MRP). We found that treatment of LyECs isolated from internal iliac lymphatic vessels with IFNT stimulated LyEC proliferation and significantly increased mRNA expression of VEGFC and IFN-stimulated gene 15. Moreover, both IFNT and VEGFC induced LyECs to form capillary-like tubes in vitro. In conclusion, it is suggested that new lymphangiogenesis in the bovine $\mathrm{CL}$ begins during the MRP and that IFNT may mediate this novel phenomenon.
\end{abstract}

Reproduction (2011) 142 879-892

\section{Introduction}

The corpus luteum $(\mathrm{CL})$ is the essential organ for maintaining pregnancy and accomplishes this by secreting progesterone $\left(\mathrm{P}_{4}\right)$. In the cow, the luteal phase of the estrous cycle lasts $\sim 17-18$ days, and luteal regression is induced by uterine prostaglandin $\mathrm{F}_{2 \alpha}\left(\mathrm{PGF}_{2 \alpha}\right)$ in the absence of pregnancy. By contrast, when pregnancy is established, interferon tau (IFNT), a known pregnancy recognition signal in ruminants (Imakawa et al. 1987), is secreted by embryonic trophoblast cells and indirectly maintains the CL by attenuating (cow; Meyer et al. 1995) or altering (ewe; Zarco et al. 1988a,1988b) luteolytic pulses of uterine $\mathrm{PGF}_{2 \alpha}$ beginning at approximately day 16 postinsemination; this period is therefore defined as the maternal recognition period (MRP; Spencer et al. 2004).

IFNT produced by the conceptus passes through the uterine lumen and enters the endometrium where it also apparently enters venous drainage from the uterus.
Oliveira et al. (2008) demonstrated greater antiviral activity in uterine vein blood from day 15 pregnant sheep. Preadsorption of IFNT with antiserum against recombinant ovine IFNT revealed that antiviral activity in uterine vein blood from pregnant ewes was mediated by IFNT (Bott et al. 2010). Both of these studies are interpreted to reflect the release of IFNT into the uterine vein. Interestingly, IFN-stimulated gene (ISG) 15 was upregulated in the $\mathrm{CL}$ and blood cells as well as in the endometrium during MRP in the pregnant cow and ewe (Hansen et al. 1997, Johnson et al. 1998, 1999, Han et al. 2006, Gifford et al. 2007, Yang et al. 2010). Furthermore, IFNT enhanced CL resistance to the luteolytic effect of $\mathrm{PGF}_{2 \alpha}$ in an endocrine manner, and infusion of IFNT into the uterine vein clearly inhibited spontaneous luteolysis in ewes (Bott et al. 2010). Therefore, IFNT may influence not only the uterine environment but also the $\mathrm{CL}$ in the cow via local or peripheral circulation. 
The lymphatic vascular system is considered as the body's second circulation system and is essential for maintaining interstitial fluid pressure equilibrium and transporting tissue fluid, proteins, and cells (Wang \& Oliver 2010). The lymphatic system is also crucial during the immune response to infectious agents, as lymphatic vessels are the route by which dendritic cells and macrophages migrate to the lymph nodes and lymphoid organs to present antigen to T cells. While the development of blood vessels, or angiogenesis, has been studied extensively since 1980s, the development of lymphatic vessels, or lymphangiogenesis, has attracted relatively little attention despite the clinical relevance of lymphangiogenesis to processes such as lymphedema and the metastasis of cancer cells. However, study of the lymphatic system is now accelerating due to great progress in identifying specific markers of lymphatic endothelial cells (LyECs), including lymphatic vessel endothelial hyaluronan receptor (LYVE1) and podoplanin (Banerji et al. 1999, Breiteneder-Geleff et al. 1999, Prevo et al. 2001). Importantly, two vascular endothelial growth factor (VEGF) family members, VEGFC and VEGFD, regulate the LyECs via their receptor VEGFR3 and thereby stimulate lymphangiogenesis (Joukov et al. 1997, Yamada et al. 1997, Karkkainen et al. 2004).

The vascular system is well known to be important for the function of the CL (Fraser et al. 2000, Wulff et al. 2001, Yamashita et al. 2008). The development of the bovine $\mathrm{CL}$ is accompanied by active angiogenesis, and the structure of blood vessels is retained during pregnancy (O'Shea et al. 1989, Lei et al. 1991, Beindorff et al. 2010). Leukocytes, including monocytes/macrophages, granulocytes, and T lymphocytes, are localized to the CL in several species (Standaert et al. 1991, Brannstrom et al. 1994, Reibiger \& Spanel-Borowski 2000). These findings suggest that the bovine CL should have a lymphatic system with essential roles in regulating the functions of its immune cells. Indeed, early morphological studies revealed profuse networks of lymphatic vessels in the CLs of the sheep, swine, dog, and rabbit (Andersen 1926, Czeizel \& Palkovich 1962, Morris \& Sass 1966, Murata 1976, Otsuki et al. 1987). Moreover, Xu \& Stouffer (2009a, 2009b) reported that the VEGFC/VEGFD-VEGFR3 system regulates lymphangiogenesis in and luteal structure and function of the primate CL.

Thus, this study was designed to test the hypothesis that a lymphatic network exists in the bovine $C L$ and the occurrence of lymphangiogenesis changes in the bovine $\mathrm{CL}$ during the estrous cycle and early pregnancy. Our novel finding that lymphangiogenesis is upregulated in the $\mathrm{CL}$ of pregnancy during MRP led us to investigate the possibility that IFNT affects lymphangiogenesis using LyECs in vitro.

\section{Results} LYVE1 protein and MRNA expression in the CL during
the estrous cycle and early pregnancy

Lymphatic vessels in bovine tissues were identified by immunohistochemical staining for LYVE1 (a marker of LyECs), and the localization of LYVE1-positive cells was compared with that of von Willebrand factor (VWF, a marker of the vascular endothelial cells)-positive cells (Fig. 1A-H). Serial sections stained for LYVE1 and VWF are shown in Fig. 1A-H. VWF-positive cells were presented (Fig. 1A, black arrow heads) in the lymph node, but the same blood vessels were not stained with LYVE1 (Fig. 1B, white arrow heads). In addition, some cells in the lymph node stained strongly with LYVE1 (Fig. 1B, black arrows) but not with VWF (Fig. 1A, white arrows), suggesting that LYVE1 staining is specific for lymphatic vessels in the cow.

In the mid-luteal phase, the blood vessels of the CL showed appreciable staining for VWF (Fig. 1C, black arrow heads), but the same blood vessels did not stain for LYVE1 (Fig. 1D, white arrow heads). In contrast, LYVE1-positive cells (Fig. 1D, black arrows) were clearly detected in other areas where VWF-positive cells (Fig. 1C, white arrows) were absent. LYVE1 (Fig. 1F, black arrows) and VWF (Fig. 1E, white arrows) staining in the $\mathrm{CL}$ remained discrete during pregnancy. The enlarged images in Fig. $1 \mathrm{G}$ and $\mathrm{H}$ show that LYVE1positive cells existed in different vessels from VWF-positive cells. LYVE1 expression in the CL during pregnancy was also demonstrated by immunofluorescence (Fig. 11). Intensity of the LYVE1-staining area was significantly increased from the early to the mid-luteal phase and decreased to regressing luteal phase (Fig. 1J, $P<0.05$ ).

Figure $1 \mathrm{~K}-\mathrm{N}$ shows LYVE1 mRNA and protein expression in the $\mathrm{CL}$ during the estrous cycle and early pregnancy. During the estrous cycle, LYVE1 mRNA expression increased significantly and LYVE1 protein expression tended to increase from the early to the mid-luteal $\mathrm{CL}$ (Fig. $1 \mathrm{~K}$ and $\mathrm{L}, P<0.05$ ). During early pregnancy, LYVE1 mRNA levels were greater in the center of the $C L$ at P16 and P40 and in the periphery at P40 (Fig. $1 \mathrm{M}, P<0.05$ ) than on days 12 and 16 of the estrous cycle. LYVE1 protein levels were also greater $(P<0.05)$ in the periphery of the $C L$ at $P 40$ but not in the center of the $\mathrm{CL}$ than on days 12 and 16 of the estrous cycle (Fig. $1 \mathrm{~N}$ ).

Bovine $\mathrm{CL}$ is heterogeneous tissue in which there are many arteriolovenous vessels distributed in the periphery of the $\mathrm{CL}$ compared with the center during the mid-luteal phase, while capillary vessels localized at the center more than the periphery of the CL (Shirasuna et al. 2009). Therefore, we separated the center and periphery of the $C L$ and investigated different expression of the lymphatic vessels, especially about the $C L$ of pregnancy. It is possible that lymphatic vessels exist both in the periphery and in the center of the bovine $\mathrm{CL}$ 

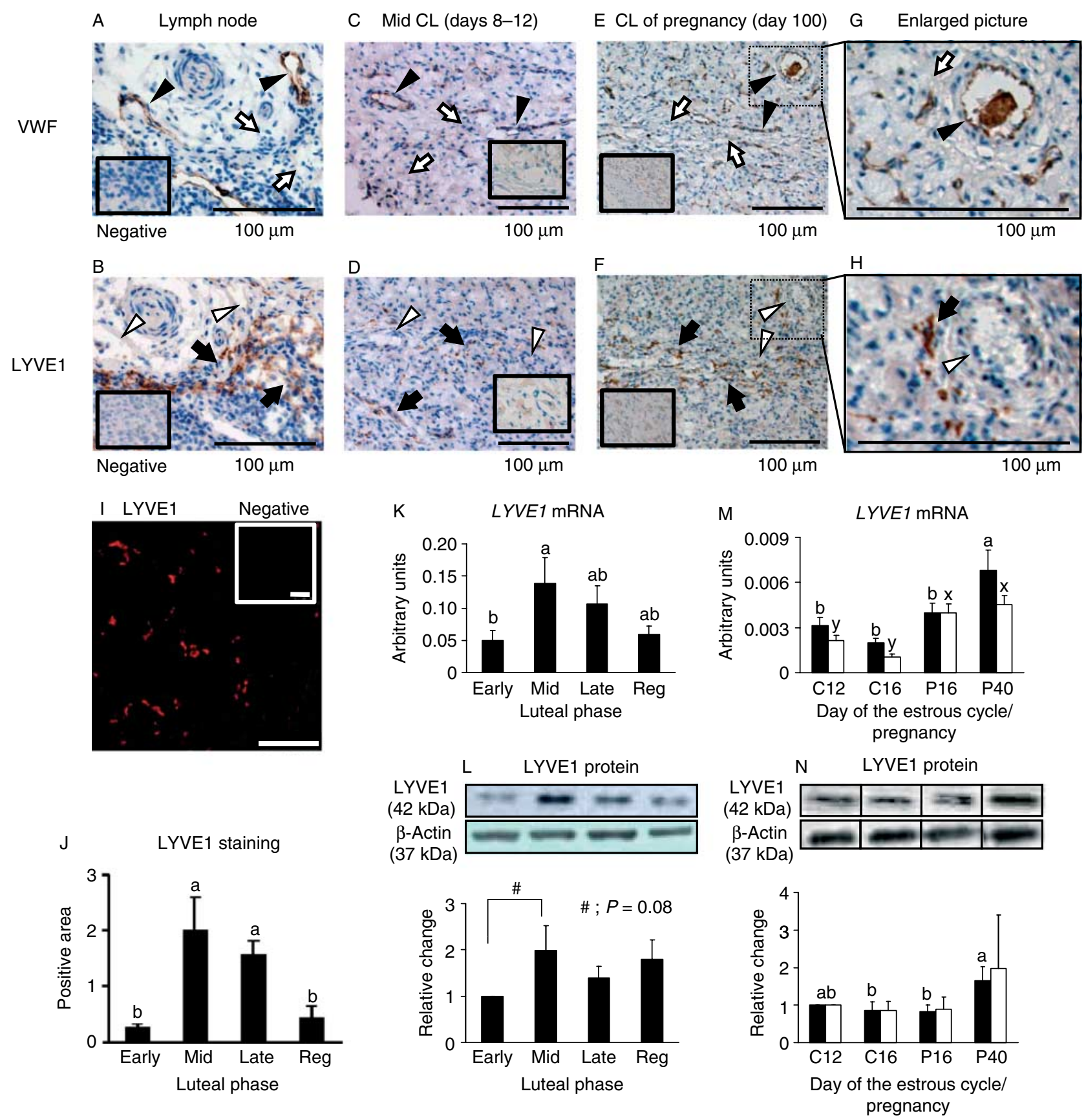

Figure 1 Localization of lymphatic and blood vessels and expression of LYVE1 mRNA and protein in the bovine corpus luteum. Immunohistochemical localization of VWF and LYVE1 in serial sections of the lymph node (A and B), the CL during the estrous cycle (C and D), the CL during pregnancy (day 100) (E and F), and enlarged images of $E$ and $F(G$ and $H)$. The blood vessels stained by VWF (A, C, E, and G, black arrow heads) were not stained by LYVE1 (B, D, F, and H, white arrow heads), while the lymphatic vessels stained by LYVE1 (B, D, F, and H, black arrows) were not stained by VWF (A, C, $\mathrm{E}$, and $\mathrm{G}$, white arrows). The different staining between VWF and LYVE1 in the tissue sections suggests that lymphatic vessels exist in the bovine CL. LYVE1-positive cells were also detected by immunofluorescent staining (I). The positive staining area of LYVE1 increased in the CL from early to midluteal phase (J, $n=3 /$ stage). Small black squares in each figure indicate negative control. The scale bars in all images represent $100 \mu \mathrm{m}$. LYVE1 mRNA expression $(\mathrm{K})$ and protein expression $(\mathrm{L})$ in the bovine $\mathrm{CL}$ during the estrous cycle $(n=4-5 /$ stage). $L Y V E 1 \mathrm{mRNA}(\mathrm{M})$ and protein (N) expression in the bovine $\mathrm{CL}$ at days 12 (C12) and 16 (C16) of the estrous cycle and at days 16 (P16) and 40 (P16) of pregnancy ( $n=5-7 /$ stage). Black bars indicate the peripheral area of the $\mathrm{CL}(\mathrm{M}$ and $\mathrm{N}$ ), while white bars indicate the central area. Representative western blots are shown for $L Y V E 1$ (42 kDa) and $\beta$-actin $(37 \mathrm{kDa})(\mathrm{L}$ and $\mathrm{N})$. All values are shown as mean \pm s.E.M. Different superscript letters ( $\mathrm{a}$ and $\mathrm{b}$; periphery of the $\mathrm{CL}, \mathrm{x}$ and $\mathrm{y} ; \mathrm{center}$ of the $\mathrm{CL}$ ) indicate significant differences $(P<0.05)$ and \# indicates tendency to difference $(P<0.1)$ as determined by ANOVA followed by Fisher's multiple comparison test. 

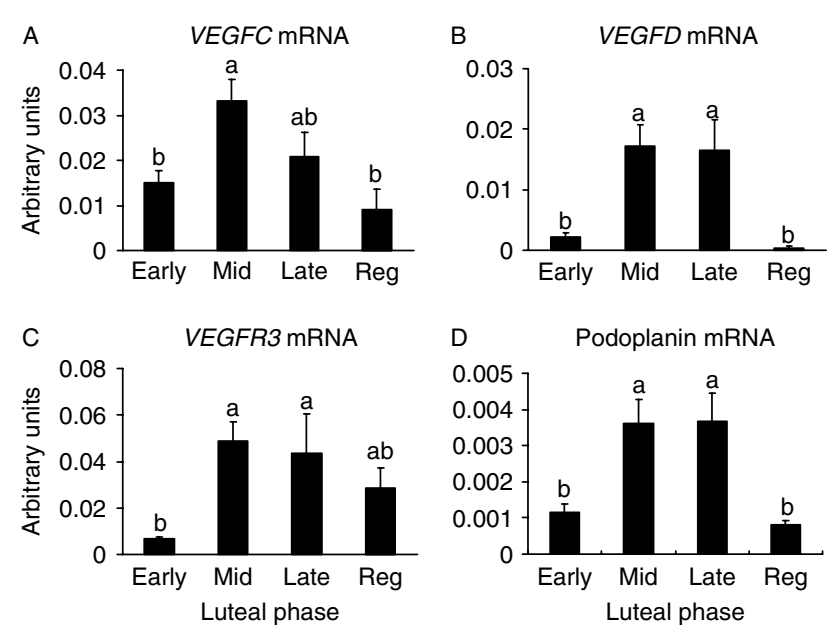

Figure 2 mRNA expression of $V E G F C, V E G F D, V E G F R 3$, and podoplanin in the bovine $C L$ during the estrous cycle. mRNA expression of $\operatorname{VEGFC}(\mathrm{A}), \operatorname{VEGFD}(\mathrm{B}), \operatorname{VEGFR} 3(\mathrm{C})$, and podoplanin (D) increased in the $\mathrm{CL}$ from the early to the mid-luteal phase and decreased to regressing luteal phase (mean \pm S.E.M., $n=4-5 /$ stage). Different superscript letters indicate significant differences $(P<0.05)$ as determined by ANOVA followed by Fisher's multiple comparison test.

because of the expression of LYVE1 protein and mRNA in both area of the CL. LYVE1 protein expression was greater in the periphery of the CL of P40 but not in the center (Fig. $1 \mathrm{~N}$ ), indicating the possibility that lymphatic vessels are remodeled especially in the periphery of the $\mathrm{CL}$ during pregnancy.

The mRNA expression of lymphangiogenic factors and a LyEC marker during the estrous cycle and early pregnancy

The mRNA expression levels of lymphangiogenic factors (VEGFC, VEGFD, and VEGFR3) and a LyEC marker (podoplanin) in the $\mathrm{CL}$ during the estrous cycle are shown in Fig. 2. The mRNA expression of all factors significantly increased $(P<0.05)$ from the early to the mid-luteal phase (Fig. 2A-E). The mRNA expression levels of VEGFC, VEGFD, and podoplanin decreased $(P<0.05)$ during luteal regression (Fig. $2 \mathrm{~A}, \mathrm{C}$, and $\mathrm{D})$.

The mRNA expression levels of VEGFC, VEGFD, and VEGFR3 and podoplanin in the $\mathrm{CL}$ during early pregnancy are shown in Fig. 3. VEGFC mRNA expression was higher in the peripheral $C L$ at P16 and in the central $\mathrm{CL}$ at P40 compared with $\mathrm{C} 16$ (Fig. 3A, $P<0.05$ ). VEGFD and VEGFR3 mRNA levels were higher in the peripheral and in the central CL at P16 compared with C16. Although VEGFD mRNA expression in the CL decreased from P16 to P40, VEGFR3 mRNA in the peripheral $C L$ was maintained at a higher level at $\mathrm{P} 40$ compared with P16 (Fig. 3B and C, $P<0.05$ ). In addition, podoplanin $m R N A$ expression was significantly higher in the peripheral $\mathrm{CL}$ at P16 compared with $\mathrm{C} 16$ and further increased in the peripheral and central $\mathrm{CL}$ at $\mathrm{P} 40$ compared with P16 (Fig. 3D, $P<0.05$ ).

\section{Characteristics of LyECs compared with luteal endothelial cells}

To investigate the purity of LyECs, the mRNA and protein expression levels of lymphatic markers were compared between isolated LyECs and luteal endothelial cells (LECs; Fig. 4). LyECs but not LECs strongly expressed podoplanin (LyEC marker) mRNA (Fig. 4A, P<0.01). Figure $4 \mathrm{~B}$ shows light field of LyECs. By immunofluorescence, LyECs were stained with LYVE1 antibody (Fig. 4C), while LECs did not express LYVE1 protein (Fig. 4D). LyECs stained without primary antibody, as a negative control did not show LYVE1 staining (Fig. 4E). In contrast, previous studies showed that same LECs were stained with VWF (Klipper et al. 2004), but VWF protein did not express in LyECs in this study (data not shown). These results indicated that isolated LyECs had specific characteristics of LyECs.

\section{The mRNA expression levels of lymphangiogenic factors in LyECs compared with LECs, luteal cells, and immune cells}

Immune cells have an important role in lymphangiogenesis because inflammatory cells such as monocytes/ macrophage can secret VEGFC and VEGFD, inducing inflammatory lymphangiogenesis (Cursiefen et al. 2004, Baluk et al. 2005, Iwata et al. 2007). We determined the mRNA expression levels of lymphatic-related factors in peripheral blood mononuclear cells (PBMCs), polymorphonuclear neutrophils (PMNs), luteal cells (LCs), LECs, and LyECs (Fig. 5). LyECs, LECs, and LCs expressed
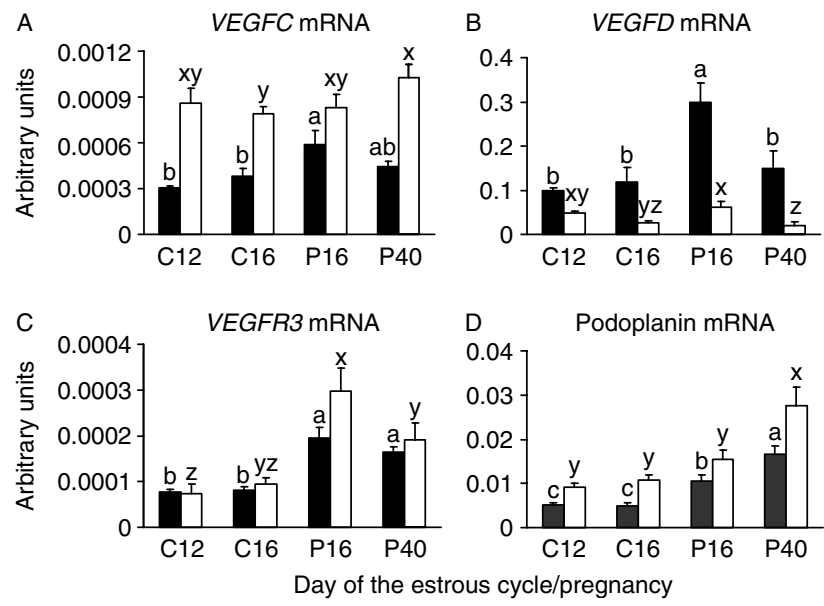

Figure 3 mRNA expression of VEGFC, VEGFD, VEGFR3, and podoplanin in the bovine $C L$ during early pregnancy. mRNA expression of $\operatorname{VEGFC}(\mathrm{A}), \operatorname{VEGFD}(\mathrm{B}), \operatorname{VEGFR} 3(\mathrm{C})$, and podoplanin (D) increased in the $\mathrm{CL}$ of day 16 (P16) or day 40 (P40) during pregnancy compared with day 12 (C12) and/or day 16 (C16) during the estrous cycle (mean \pm s.E.M., $n=5-7 /$ stage). Black bars indicate the peripheral area of the $\mathrm{CL}$, while white bars indicate the central area. Different superscript letters ( $\mathrm{a}$ and $\mathrm{b}$; periphery of the $\mathrm{CL}, \mathrm{x}$ and $\mathrm{y}$; center of the $\mathrm{CL}$ ) indicate significant differences $(P<0.05)$ as determined by ANOVA followed by Fisher's multiple comparison test. 
A

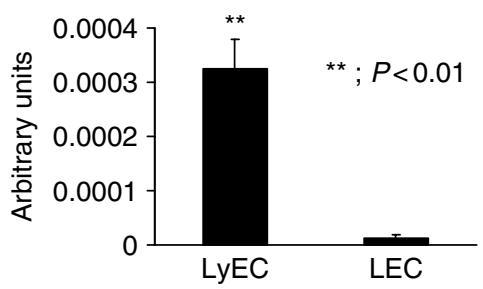

B LyECs

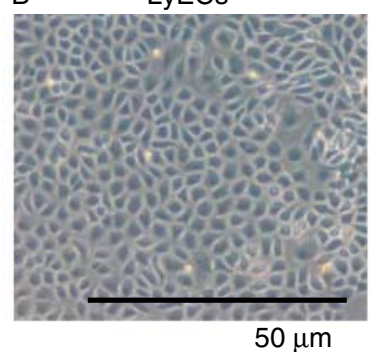

LYVE1 protein on LyECs

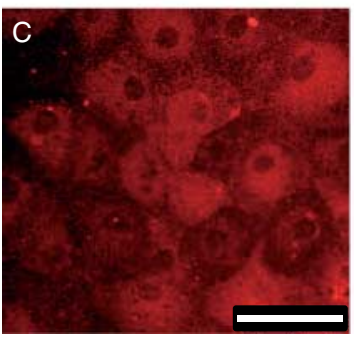

$50 \mu \mathrm{m}$

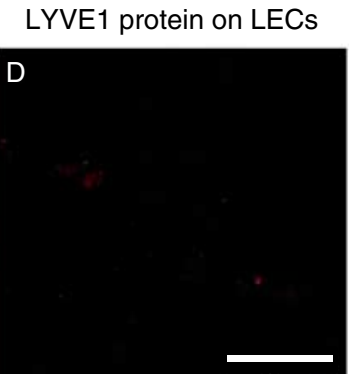

$50 \mu \mathrm{m}$

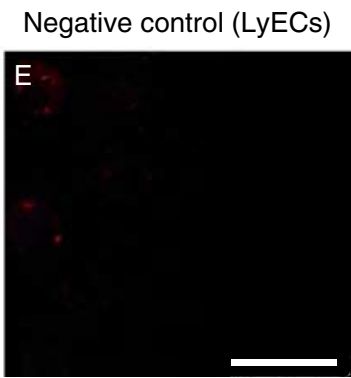

$50 \mu \mathrm{m}$
Figure 4 Characteristics of LyECs compared with LECs. Podoplanin mRNA was expressed mainly in LyECs but not in LECs (A) (mean \pm s.E.M., $n=5$ /group). B shows the light field of LyECs. LYVE1 protein was detected only in LyECs (C) but not in LECs (D) using immunofluorescence. E shows a negative control for LYVE1. The scale bars represent $50 \mu \mathrm{m}$. ${ }^{* *}$ Significant differences $(P<0.01)$ as determined by Student's $t$-test.
VEGFC mRNA (Fig. 5A, $P<0.05$ ), and expression levels of VEGFC mRNA were higher in LyECs than in LECs and LCs (Fig. 5A, $P<0.05$ ). PBMCs and PMNs did not express VEGFC mRNA (Fig. 5A, $P<0.05$ ). In contrast, VEGFD mRNA was expressed in PBMCs and PMNs but not in LCs, LECs, or LyECs (Fig. 5B). VEGFR3 mRNA, which is a marker of LyECs, was expressed only in LyECs (Fig. 5C).

\section{Effects of IFNT or IFNA on ISG15, VEGFC, and VEGFR3 mRNA expression in LyECs and LECs}

We investigated whether IFNT has the specific effects for LyECs compared with IFN $\alpha$ (IFNA), which belongs to type 1 IFN as well as IFNT. The changes in ISG15, VEGFC, and VEGFR3 mRNA expression levels in LyECs and LECs after treatment with IFNT or IFNA $(0.6,6$, or $60 \mathrm{IU} / \mathrm{ml})$ are shown in Fig. 6. IFNT increased ISG15 mRNA expression in a dose-dependent manner in both LyECs and LECs (Fig. 6A and D). In addition, IFNT at $60 \mathrm{IU} / \mathrm{ml}$ stimulated VEGFC mRNA expression in LyECs (Fig. 6B, $P<0.05$ ) but had no effect on VEGFR3 mRNA expression (Fig. 6C). In LECs, $V E G F C$ mRNA levels tended to increase on treatment with IFNT at $60 \mathrm{IU} / \mathrm{ml}$ (Fig. $6 \mathrm{E}, P<0.1$ ). IFNA also stimulated ISG15 expression in LyECs at $6 \mathrm{IU} / \mathrm{ml}$ and in LECs at $60 \mathrm{IU} / \mathrm{ml}$ (Fig. $6 \mathrm{~F}$ and I, $P<0.05$ ). However, IFNA at $0.6 \mathrm{IU} /$ $\mathrm{ml}$ decreased VEGFC mRNA expression in LyECs (Fig. 6G, $P<0.1$ ) and had no effect in LECs (Fig. 6J). IFNA also had no effect on VEGFR3 mRNA expression in LECs (Fig. 6H).

\section{Effects of IFNT on proliferation of LyECs and capillary-like tube formation}

We next examined the effects of IFNT on the proliferation of LyECs and capillary-like tube formation of LyECs in vitro (Fig. 7A-E). The data show that IFNT at $6 \mathrm{IU} / \mathrm{ml}$ stimulated proliferation of LyECs compared with the control after $24 \mathrm{~h}$ (Fig. 7A, $P<0.05$ ). We also assessed capillary-like tube formation in response to IFNT. In an in vitro matrigel assay, both IFNT $(60 \mathrm{IU} / \mathrm{ml})$ and VEGFC $(100 \mathrm{ng} / \mathrm{ml})$ stimulated LyECs to assemble into capillarylike structures (Fig. 7B-E, $P<0.01$ ). Lower concentration of IFNT $(6 \mathrm{IU} / \mathrm{ml})$ tends to promote capillary-like structures of LyECs (Fig. 7B, $P<0.1$ ).

\section{Discussion}

In this study, we have performed a detailed analysis of the lymphatic system of the bovine $C L$ during the estrous cycle and early pregnancy. The mRNA expression levels of LyEC markers and lymphangiogenic factors were markedly higher in the $C L$ during the MRP than during the estrous cycle. Therefore, we hypothesized that IFNT produced by trophectoderm cells of the developing conceptus during the MRP stimulates the $\mathrm{CL}$ to upregulate the mRNA expression of lymphatic-related factors. In fact, IFNT increased VEGFC mRNA expression in LyECs and promoted the proliferation and tube formation of LyECs in vitro. Although the effects of IFNT on CL-derived LyECs remain to be investigated, the present results suggest the possibility that IFNT regulates lymphangiogenesis in the early pregnant $\mathrm{CL}$ during the MRP.

I.u. administration of IFNT has been shown to inhibit the release of $\mathrm{PGF}_{2 \alpha}$ due to suppression of oxytocin receptor (OXTR) expression in the endometrium (Spencer \& Bazer 1996, Chen et al. 2006). In addition, OXTR is regulated primarily by receptors for estrogen receptor $\alpha$ (ESR1; Spencer \& Bazer 1996, Spencer et al. 2004). 

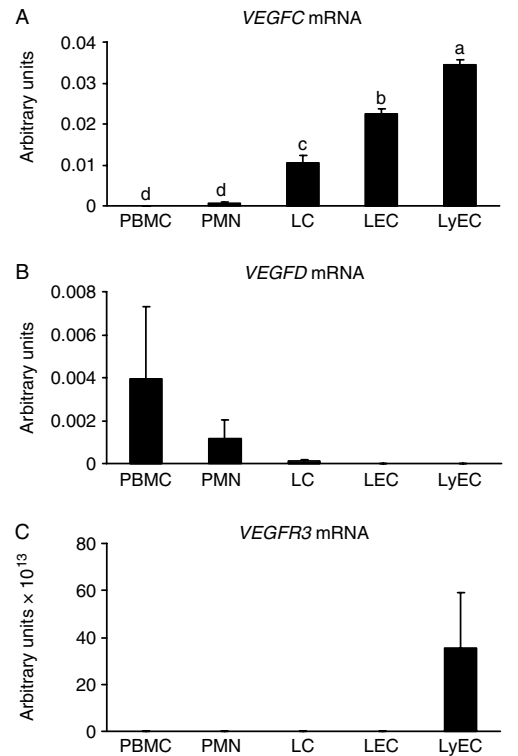

Figure 5 The mRNA expression of lymphangiogenic factors in LyECs compared with LECs, luteal cells, and immune cells. VEGFC mRNA was detected mainly in LCs, LECs, and LyECs but not in PBMCs and PMNs (A). In contrast, PBMCs and PMNs expressed VEGFD mRNA (B). VEGFR3 mRNA was expressed only in LyECs (C). All values are shown as mean \pm s.E.M. ( $n=5 /$ group). Different superscript letters indicate significant differences $(P<0.05)$ as determined by ANOVA followed by Fisher's multiple comparison test.

While ESR1 is up-regulated during the estrous cycle, that upregulation is blocked by IFNT in pregnant ewes (Spencer et al. 1995, Fleming et al. 2006). A s.c. injection of IFNT had no effect on the expression of ER and OXTR in the ewe, suggesting that IFNT acts only within the uterus (Spencer et al. 1999). However, IFNT produced by the conceptus was recently shown to pass through the uterine lumen and enter the uterine vein (Oliveira et al. 2008, Bott et al. 2010). In addition, ISG15 mRNA expression in both the endometrium and the $\mathrm{CL}$ is upregulated during MRP in the pregnant ewe and cow compared with the cyclic animal (Hansen et al. 1997, Johnson et al. 1998, 1999, Yang et al. 2010). ISG15 mRNA were highly expressed in endometrium and $\mathrm{CL}$, but not in liver, from day 15 pregnant ewes compared with nonpregnant ewes, suggesting some degree of countercurrent exchange of IFNT from the uterine vein to the ovarian artery during pregnancy (Bott et al. 2010). It has been proposed that IFNT may have endocrine action through inducing $\mathrm{CL}$ resistance to $\mathrm{PGF}_{2 \alpha}$ and long-term survival of the $\mathrm{CL}$ and maintenance of pregnancy (Hansen et al. 2010). The mRNA expression of IFNT by the bovine conceptus peaked on day 16 of pregnancy (Farin et al. 1990), the same time at which the increased expression of lymphangiogenic factors such as LYVE-1, VEGFC, $V E G F D$, and VEGFR3 was evident in this study (Figs $1 \mathrm{M}, \mathrm{N}$ and 3), suggesting that the upregulation of lymphatic-related factors in the bovine $\mathrm{CL}$ during the MRP may be related to IFNT.
Bovine $\mathrm{CL}$ consists of various cell types including LCs, vascular endothelial cells, smooth muscle cells, fibroblasts, and immune cells (O'Shea et al. 1989, Lei et al. 1991, Zheng et al. 1993, Penny 2000). Therefore, we first examined the mRNA expression of the lymphangiogenic factors in various cells, including LCs and LECs, isolated from the CL, LyECs isolated from the internal iliac lymphatic vessels, and PBMCs and PMNs isolated from peripheral blood (Fig. 5). LyECs, LECs, and LCs have a potential of producing VEGFC. In contrast, immune cells such as PMN and PBMC have a potential of producing VEGFD. It is therefore possible that several cell types in the bovine $\mathrm{CL}$ can induce lymphangiogenesis.

VEGFC is recognized to be more potent than VEGFD for activating lymphangiogenesis. Deletion of VEGFC leads to complete absence of the lymphatic vasculature and death in mouse embryos (Karkkainen et al. 2004). By contrast, while deletion of VEGFD does not affect the development of lymphatic vessels, exogenous VEGFD protein rescues the impaired vessel sprouting of VEGFC ${ }^{-/-}$embryos (Karkkainen et al. 2004, Baldwin et al. 2005). Therefore, we focused on LyECs and LECs, both of which abundantly expressed VEGFC mRNA and could thus contribute to lymphangiogenesis. In particular, we examined the hypothesis that IFNT is related to the upregulation of VEGFC in the CL during the MRP. As expected, IFNT stimulated the mRNA expression of not only ISG15 but also VEGFC in both LyECs and LECs (Fig. 6). Although VEGFC stimulated LyECs to form tubes, as in previous studies (Podgrabinska et al. 2002, Zeng et al. 2006), IFNT promoted comparable levels of LyEC proliferation and capillary-like tube formation (Fig. 7). The data indicate that IFNT can induce lymphangiogenesis in cows by stimulating VEGFC expression in both LyECs and LECs, suggesting that IFNT might be responsible for the increase of lymphangiogenic factors in the bovine $\mathrm{CL}$ during early pregnancy.

IFNs are typically classified as either type 1 or type 2 . Type 1 IFNs comprise IFNA, IFN $\beta$, and IFNT and defense against infection by pathogens is considered to be the main function of this group (Roberts et al. 1996, Spencer et al. 2004). IFNT has sequence similarity $(\sim 50 \%$ amino acid identity) and functional homology to IFNA (Roberts et al. 1992). All type 1 IFNs bind to common receptors such as IFNA receptor 1 (IFNA R1) and IFNA R2 (Li \& Roberts 1994) and induce several common genes (Teixeira et al. 1997, Staggs et al. 1998, Hansen et al. 1999, Asselin et al. 2001, Choi et al. 2001). It is therefore possible that the IFNT-induced lymphangiogenesis shown in this study is not specific and that IFNA can also activate lymphangiogenesis. In contrast with the effect of IFNT on LyECs, IFNA tended to decrease VEGFC mRNA expression in LyECs despite stimulating ISG15 mRNA expression. Although IFNT increased mRNA expression of both VEGFC and ISG15 in LECs, IFNA upregulated ISG15 mRNA expression but 


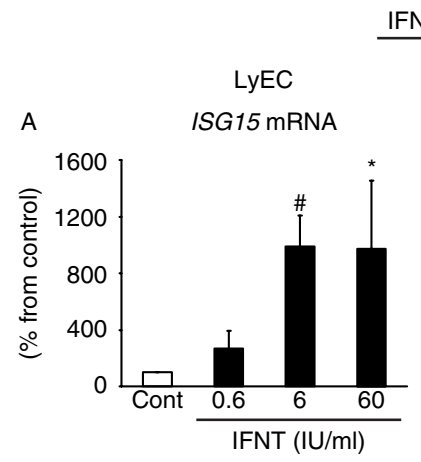

IFNT treatment
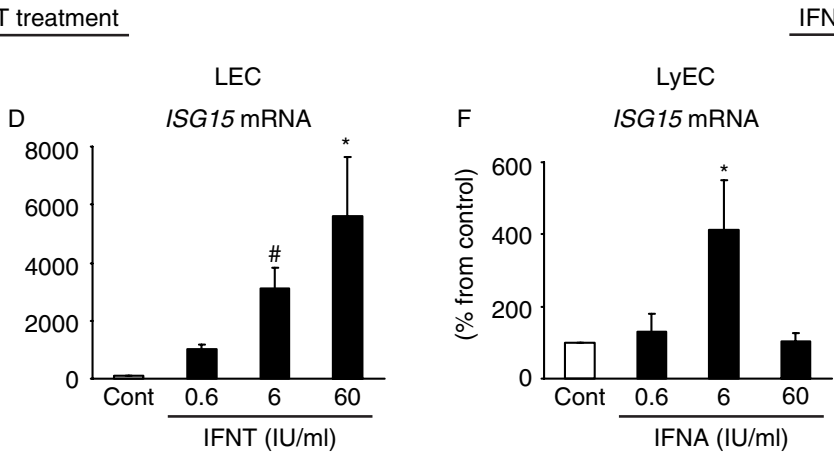

FNA treatment
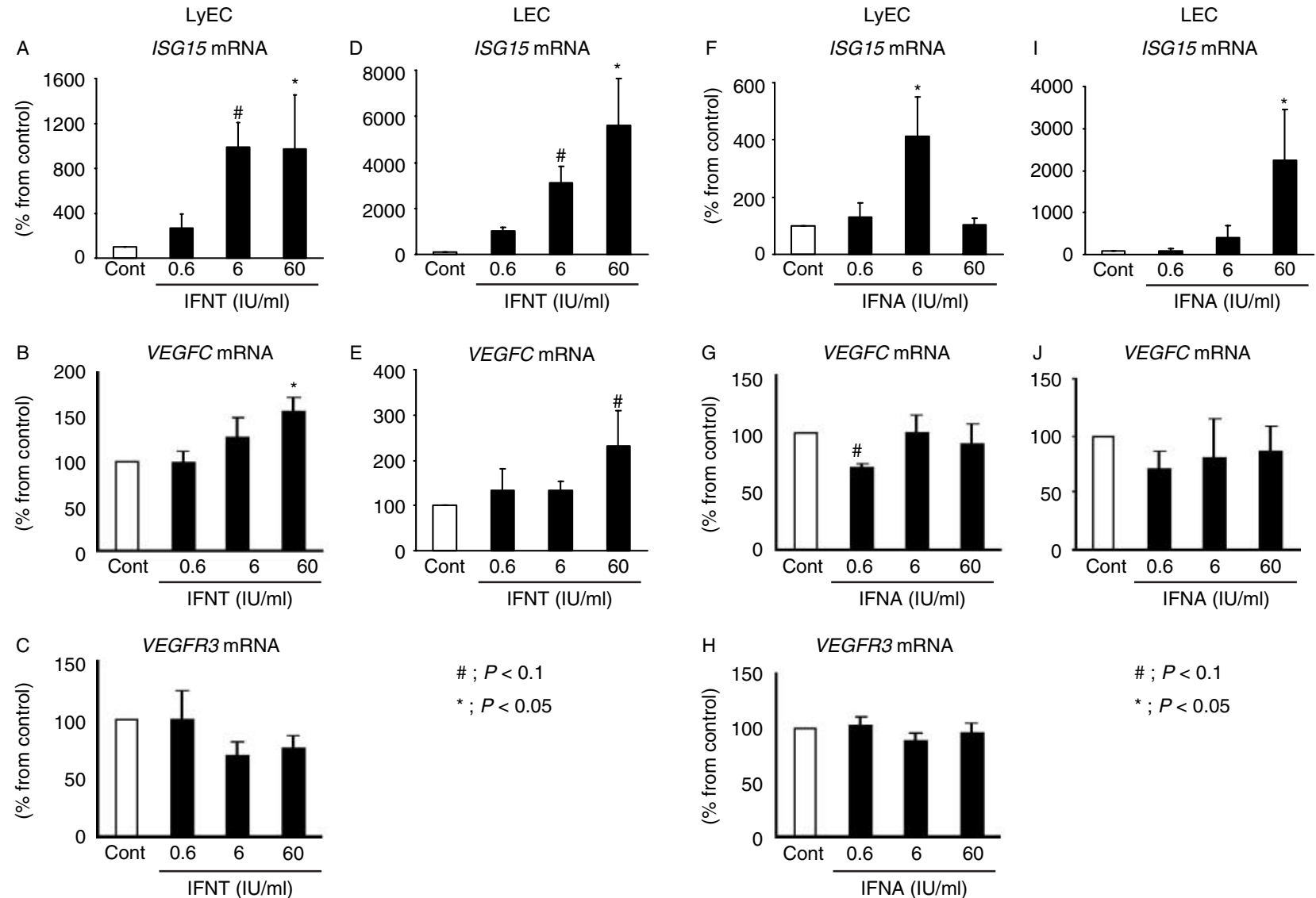

$$
\begin{aligned}
& \# ; P<0.1 \\
& { }^{*} ; P<0.05
\end{aligned}
$$

$$
\begin{aligned}
& \# ; P<0.1 \\
& { }^{*} ; P<0.05
\end{aligned}
$$

Figure 6 Effects of IFNT or IFNA on ISG15, VEGFC, and VEGFR3 mRNA expression in LyECs and LECs. IFNT stimulated mRNA expression of ISG15 and VEGFC but not VEGFR3 in LyECs (A-C). IFNT also stimulated ISG15 and VEGFC mRNA expression in LECs (D and E). In contrast, IFNA stimulated ISG15 mRNA expression (F) but tended to decrease VEGFC mRNA expression in LyECs (G). IFNA had no effect on VEGFR3 mRNA expression (H). In LECs, IFNA stimulated ISG15 mRNA expression but not VEGFC mRNA expression (I and J). White bars indicate the control group (no treatment), while black bars indicate $0.6-60 \mathrm{IU} / \mathrm{ml}$ IFNT-treated or IFNA-treated groups. All values are shown as mean \pm s.E.M. ( $n=4 /$ group). *Significant differences $(P<0.05)$ and ${ }^{\#}$ tendency to difference $(P<0.1)$ as determined by ANOVA followed by Fisher's multiple comparison test.

not VEGFC mRNA expression in LECs. In fact, Green et al. (2005) reported different effects of IFNT and IFNA in the ewe, with IFNT treatment resulting in enhanced $\mathrm{P}_{4}$ production without luteolysis while treatment with IFNA did not affect $\mathrm{CL}$ function and allowed normal regression of the CL. Moreover, Nagaoka et al. (2003) also showed a specific effect of IFNT distinct from that of IFNA. While both IFNT and IFNA stimulated the expression of IFN $\gamma$-inducible protein $10 \mathrm{kDa}$ (IP-10) by monocytes, the expression of IP-10 mRNA by endometrial explants in vitro was much more effectively stimulated by IFNT (Nagaoka et al. 2003).

The mRNA and protein expression levels of the lymphangiogenic factors and a marker of lymphatic vessels in the bovine $C L$ changed significantly between the early and the mid-luteal phases of the estrous cycle (Figs 1J, K, L and 2). In agreement with our results, Xu \& Stouffer $(2009 a, 2009 b)$ revealed that lymphatic vessels are present in the primate $C L$ and that mRNA levels of
VEGFC, VEGFD, and VEGFR3 changed throughout the menstrual cycle. Furthermore, an injection of soluble VEGFR3 (which acts as an anti-VEGFR3 antibody) into the preovulatory follicle inhibited follicle rupture/ ovulation and suppressed $\mathrm{P}_{4}$ production in the monkey CL (Xu \& Stouffer 2009a, 2009b). In addition, the bovine $\mathrm{CL}$ is known to be a highly vascularized organ, and its development and regression are regulated locally by many angiogenic and vasoactive factors (Girsh et al. 1996, Skarzynski et al. 2000, Miyamoto et al. 2009, 2010, Robinson et al. 2009). The mRNA expression of VEGFA and fibroblast growth factor-2 (FGF2), which are the major factors regulating angiogenesis throughout the luteal phase, is highest immediately after ovulation (Berisha et al. 2000, Schams \& Berisha 2004, Woad et al. 2009). Interestingly, both VEGFA and FGF2 have potent lymphangiogenic activity (Kubo et al. 2002, Cursiefen et al. 2004). VEGFC can stimulate both lymphangiogenesis (via VEGFR3) and angiogenesis 
A
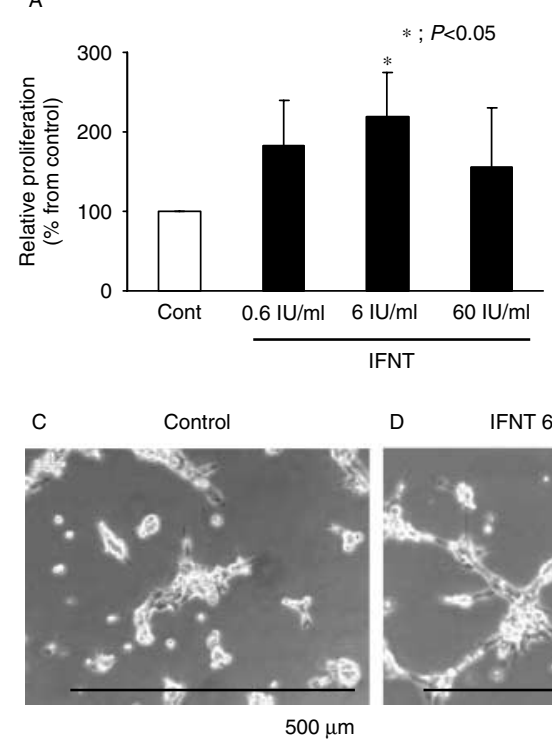

D IFNT $60 \mathrm{IU} / \mathrm{ml}$

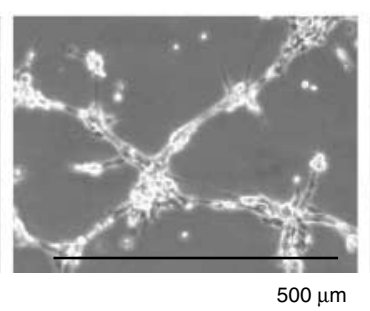

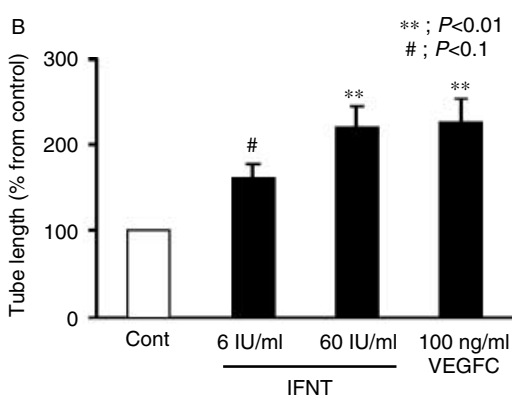

E VEGFC $100 \mathrm{ng} / \mathrm{ml}$

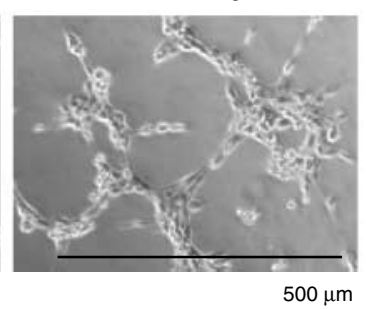

Figure 7 Effects of IFNT on proliferation of LyECs and capillary-like tube formation. IFNT stimulated the proliferation of LyECs (A) and promoted the capillary-like tube formation of LyECs as well as $100 \mathrm{ng} / \mathrm{ml}$ VEGFC (B). Panels C, D and E show typical images of capillary-like tube formation in matrigel assays on LyECs. All values are shown as mean \pm s.E.M. ( $n=4$ /group). The scale bars represent $500 \mu \mathrm{m} . *, * *$ Significant differences $(P<0.05$ or $P<0.01)$ and ${ }^{\#}$ tendency to difference $(P<0.1)$ as determined by ANOVA followed by Fisher's multiple comparison test. (via VEGFR2; Millauer et al. 1993, Shalaby et al. 1995, Wilting et al. 1997). Therefore, multiple vascular growth factors may induce lymphangiogenesis and angiogenesis in the developing bovine CL. Lymphatic vessels also appear to degenerate with blood vessels during luteal regression. This concept is supported by a previous report that mRNA expression levels of VEGFC, VEGFD, and LYVE1 were reduced in the bovine $\mathrm{CL}$ after $\mathrm{PGF}_{2 \alpha}$ injection (Schams et al. 2009).

In summary, the present results demonstrate the existence of lymphatic vessels in the bovine $C L$ and provide evidence that the increase in lymphangiogenic factors in the $C L$ in the cow begins during the MRP. Importantly, IFNT has the potential to promote lymphangiogenesis by increasing VEGFC, which is also likely present in the bovine $\mathrm{CL}$ during the MRP.

\section{Materials and Methods}

CLs were collected at the Clinic for Cattle, University of Veterinary Medicine Hannover, Germany, and blood was collected at the Field Center of Animal Science and Agriculture, Obihiro University. Each experimental procedure complied with the ethics committee on animal rights protection, Oldenburg, Germany, in accordance with German legislation on animal rights and welfare (file reference number 33.9-42502-04-07/1275) and the Guidelines for the Care and Use of Agricultural Animals of Obihiro University.

\section{Reagents}

DMEM/nutrient mixture and Ham's F-12 medium (1:1), PBS, amphotericin B, gentamicin, streptomycin and penicillin $G$ solution, collagenase from clostridium histolyticum type IV, Tween 20, anti- $\beta$-actin mouse monoclonal (clone AC-15 antibody), ECL Western Blotting Detection System, and 0.3\%
$\mathrm{H}_{2} \mathrm{O}_{2}$ were purchased from Sigma; BSA was purchased from Wako (Osaka, Japan); TRIzol reagent and rabbit anti-rabbit conjugated to Alexa 568 IgG were purchased from Invitrogen Corporation; tissue and cell culture plates (48- and 24-wells/ plate) were purchased from Nunc (Roskilde, Denmark); optimal cutting temperature (OCT) compound was purchased from Sakura Finetechnical (Tokyo, Japan); GNRH was purchased from Intervet (Unterschleißheim, Germany); DNase using a commercial kit was purchased from SV total RNA Isolation System: Promega Co.; THE RNA storage Solution was purchased from Ambion, Inc. (Austin, TX, USA); DNA purification kit SUPRECTM-01 was purchased from TaKaRa Bio. Inc. (Otsu, Japan); 4\% Block Ace Powder was purchased from DS Pharma Biomedical (Osaka, Japan); anti-mouse-LYVE1 rabbit polyclonal antibody was purchased from Abcam (Cambridge, UK); BD Matrigel basement membrane was purchased from BD Biosciences (Bedford, MA, USA); recombinant human VEGFC was purchased from ProSci (Poway, CA, USA); protease inhibitor cocktail was purchased from Roche; $70 \mu \mathrm{m}$ filter (Cell Straner, REF 352350) was purchased from BD Falcon (Franklin Lakes, NJ, USA); PVDF membranes were purchased from Bio-Rad Laboratories; lymphoprep was purchased from AxisShield (Oslo, Norway); HRP-conjugated anti-rabbit IgG antibodies were purchased from GE Healthcare Ltd (Chalfont St Giles, UK); HRP-conjugated anti-mouse IgG antibodies were purchased from Rockland Immunochemicals, Inc. (Gilbertsville, PA, USA); anti-human VWF rabbit polyclonal antibody (clone A0082) was purchased from Dako Denmark A/S (Glostrup, Denmark); biotinylated goat anti-rabbit BA-1000 IgG and avidin-biotin reagent (PK-6100, Vectastain ABC kit) were purchased from Vector Laboratories, Inc. (Burlingame, CA, USA); recombinant bovine IFN was produced by Escherichia coli. Briefly, bovine IFN cDNA (bTP-509A, gifted by Dr RM Roberts, University of Missouri) was inserted into pET-21a (Invitrogen) E. coli expression vector. This vector was then introduced into the BL21pLys (DE3) strain (Invitrogen) and the expression of the gene was induced by IPTG (Sigma). The 
produced protein was deposited in inclusion body; therefore, it was solubilized by denature and renature processes. After purification of the crude IFN by HPLC, its activity as determined in a viral resistance assay using bovine kidney MDBK cells was found to be $59050 \mathrm{IU} / \mathrm{ml}\left(5.95 \times 10^{5} \mathrm{IU} / \mathrm{mg}\right.$ and $\left.456 \mu \mathrm{M}\right)$ and evaluated by prolongation of CL life span following its infusion into the uterine horn; recombinant bovine IFN was purchased from Kingfisher Biotech (St Paul, MN, USA). The specific activity as determined in avail resistance assay using bovine kidney MDBK cells was found to be $9000 \mathrm{IU} / \mathrm{ml}$.

\section{Collection of the bovine CLs}

\section{CLs during the estrous cycle and pregnancy}

Ovaries were collected from a local slaughterhouse in Japan and CLs were classified according to stage of the estrous cycle by macroscopic observation as described previously (size, consistency, connective tissue, and mucus; Miyamoto \& Schams 1991). The stages of the estrous cycle were estimated as follows: early (days 3-5), mid (days 8-12), late (days 13-15), and regression (day $18<$ ) of the estrous cycle ( $n=4-5$ in each stage). Additionally, CLs were obtained from pregnant cows that were confirmed to have fetus (estimated fetal ages from fetal crown-rump length for $\sim 100$ days of pregnancy).

\section{CLs during early pregnancy}

Seven normal cyclic German Holstein cows were used as in previous in vivo study in Germany (Beindorff et al. 2010). Briefly, the animals were divided into four groups: ovariectomy was performed on days 12 and 16 (C12 and C16, $n=5$ ) of the estrous cycle (not inseminated) as well as on days 16 and 40 (P16 and P40, n=5-7) of pregnancy. We selected day 16 after $\mathrm{Al}$ as the transitional phase to pregnancy (MRP) and day 40 as establishment phase of pregnancy (implantation of embryo), in comparison with the mid and late luteal phase (days 12 and 16) during the estrous cycle. To determine the exact day of ovulation, all cows received GNRH (0.01 mg buserelin, $2.5 \mathrm{ml}$ of receptal), followed 7 days later by $\mathrm{PGF}_{2 \alpha}$ and then received $\mathrm{GNRH}$ at $48 \mathrm{~h}$ after $\mathrm{PGF}_{2 \alpha}$. Only animals that had a pre-ovulatory follicle by the last GNRH application attended the study. Artificial inseminations were carried out 12 and $24 \mathrm{~h}$ after GNRH application. Two days after GNRH, ovulation (=day 1) was approved by ultrasonography in all animals. To check the pregnancy for day 16 inseminated cows, the cows were killed after ovariectomy and we determined the presence of an embryo within the uterus. In this collection, CLs obtained from early pregnant cows were performed in the periphery and the center of the CL separately as in our previous study (Shirasuna et al. 2008).

To use immunohistochemical analysis, CLs were fixed with $4 \%$ paraformaldehyde and embedded in OCT compound according to make frozen tissue specimens. The $\mathrm{CL}$ tissue samples were collected, minced, and then immediately placed into a $1.5 \mathrm{ml}$ microcentrifuge tube with or without $400 \mu \mathrm{l}$ TRIzol reagent and stored at $-80{ }^{\circ} \mathrm{C}$ until analysis.

\section{Collection of bovine lymph nodes}

The lymph nodes were taken from cattle freshly dissected at Obihiro University. The lymph nodes were temporarily stored in warm PBS and processed within $30 \mathrm{~min}$ of collection. For immunohistochemical analysis, lymph nodes were fixed with $4 \%$ paraformaldehyde and embedded in OCT compound as for frozen tissue specimens. The remaining lymph nodes were prepared for molecular biology purposes.

\section{Isolation of PBMCs and PMNs}

PBMCs and PMNs were isolated from whole blood collected from the jugular vein (Jiemtaweeboon et al. 2011). PBMCs and PMNs were isolated by centrifugation at $1000 \mathrm{~g}$ for $30 \mathrm{~min}$ at $10{ }^{\circ} \mathrm{C}$ over lymphoprep. After PBMCs were collected, the plasma and buffy coat were discarded to collect the PMN. Hypotonic distilled water was added to the PBMCs and PMNs for $\sim 10 \mathrm{~s}$ to remove red blood cells. Isotonicity was restored by the addition of twice concentrated PBS and cells were collected by centrifugation at $500 \mathrm{~g}$ for $10 \mathrm{~min}$ at $10^{\circ} \mathrm{C}$. This lysis procedure was repeated on the cell pellet two times. Isolated immune cells were stored at $-80^{\circ} \mathrm{C}$ until analysis of mRNA expression.

\section{Isolation and culture of LyECS}

Methods for isolation and culture of bovine LyECs were adapted from previously established methods in cows (Leak et al. 1999, Nguyen et al. 2007). Sections of the internal iliac lymphatic vessels were taken from cattle freshly dissected at Obihiro University. Trypan blue, which is injected into the internal iliac lymph node, outlined the internal iliac lymphatic vessels, but not blood vessels. Trypan blue-stained lymphatic vessels were cut from surrounding fatty tissue and blood vessels that were not filled with trypan blue. The lymphatic vessels were stored temporarily in warm PBS and processed within $30 \mathrm{~min}$ of collection. Connective and adipose tissues were removed to expose the lymph nodes and vessels. Trypan blue was flushed from the excised vessels with warm PBS supplemented with $1 \%$ amphotericin B and $0.1 \%$ gentamicin. The distal ends of excised vessels were ligated with surgical suture, and the vessels were infused with a solution of $1.5 \mathrm{mg} / \mathrm{ml}$ collagenase in PBS. The vessels were occluded at both ends to trap the enzyme solution and incubated in PBS at $37^{\circ} \mathrm{C}$ for $15 \mathrm{~min}$. The released endothelial lining cells were collected, washed seven times with PBS, and plated on $1 \%$ Vitrogen pre-coated plates (24-well plates). The cells were cultured in DMEM/F-12 medium containing $5 \% \mathrm{FBS}, 1 \mathrm{M} \mathrm{NaHCO}$, gentamicin solution $(50 \mathrm{mg} / \mathrm{l})$, and amphotericin B solution $(2.5 \mathrm{mg} / \mathrm{l})$ and scratched in order to separate the LyECs from other cells such as fibroblasts. Isolated cells at passage 5-8 were used for the following experiments. Before IFN treatment, LyECs were washed twice with PBS. Cells were incubated in DMEM/F-12 medium containing 0.1\% FBS, $1 \mathrm{M} \mathrm{NaHCO}_{3}$, gentamicin solution $(50 \mathrm{mg} / \mathrm{l})$, and amphotericin B solution $(2.5 \mathrm{mg} / \mathrm{l})$ for $24 \mathrm{~h}$ at $37^{\circ} \mathrm{C}$ with the following additions: control (no further addition), IFNT $(0.6,6$, or $60 \mathrm{IU} / \mathrm{ml})$, or 
IFNA $(0.6,6$, or $60 \mathrm{lU} / \mathrm{ml})$. Each treatment was performed in duplicate in 24-well plates. At the end of the treatment period, the cells were stored at $-80{ }^{\circ} \mathrm{C}$ until analysis of mRNA expression.

\section{Isolation and culture of LCs and LECS}

The CLs of the mid luteal phase were collected at local slaughterhouse and dispersed using collagenase IV. The luteal stages were classified as mid (days 8-12) by macroscopic observation of the ovary as described earlier. LECs were isolated from the CLs as described previously (Spanel-Borowski 1991). As per the previous study, magnetic tosylactivated beads coating with BS-1 lectin binded glycoproteins on the bovine endothelial cells and can isolate only LECs from mixed cells of the bovine CL tissue. After removing of LECs (BS-1-positive cells), the rest of mixed cells were detected LCs as BS-1 lectin-negative cells (Klipper et al. 2004). LECs were cultured in DMEM/F-12 medium containing $5 \%$ FBS, $1 \mathrm{M} \mathrm{NaHCO}_{3}$, gentamicin solution $(50 \mathrm{mg} / \mathrm{l})$, and amphotericin B solution $(2.5 \mathrm{mg} / \mathrm{l})$ in 24-well plates. Before IFN treatment, LECs were washed twice with PBS. Cells were incubated in DMEM/F-12 medium containing 0.1\% FBS, $1 \mathrm{M}$ $\mathrm{NaHCO}_{3}$, gentamicin solution $(50 \mathrm{mg} / \mathrm{l})$, and amphotericin $\mathrm{B}$ solution $(2.5 \mathrm{mg} / \mathrm{l})$ for $24 \mathrm{~h}$ at $37^{\circ} \mathrm{C}$ with the following additions: control (no further addition), IFNT (0.6, 6, or $60 \mathrm{lU} / \mathrm{ml})$, or IFNA $(0.6,6$, or $60 \mathrm{lU} / \mathrm{ml})$. At the end of the treatment period, the cells were stored at $-80{ }^{\circ} \mathrm{C}$ until analysis of mRNA expression.

\section{Immunohistochemistry}

Serial sections ( $7 \mu \mathrm{m}$ thick) of the CLs were mounted on glass microscope slides coated with APS and immunohistochemistry for LYVE1 (a specific marker of LyECs) and VWF (a specific marker of endothelial cells) was performed. Sections were deparaffinized in xylene and rehydrated using decreasing concentrations of ethanol. The sections were incubated in Tris buffer $(\mathrm{pH} \mathrm{10})$ at $98{ }^{\circ} \mathrm{C}$ for $10 \mathrm{~min}$ and immersed in $0.3 \%$
$\mathrm{H}_{2} \mathrm{O}_{2}$ in methanol for $1 \mathrm{~h}$ to block endogenous peroxidase activity. Sections were then rinsed with TBS, incubated with $4 \%$ Block Ace in TBS to reduce nonspecific reactions and incubated with polyclonal antibody against LYVE1 (diluted $1: 200$ ) or VWF (diluted $1: 200$ ) at $4{ }^{\circ} \mathrm{C}$ overnight. As a negative control, the sections were incubated with goat anti-rabbit IgG overnight at $4{ }^{\circ} \mathrm{C}$. Thereafter, sections were rinsed three times for $5 \mathrm{~min}$ in TBS and incubated with biotinylated goat antirabbit $\lg \mathrm{G}(1: 400)$ at room temperature for $1 \mathrm{~h}$. Sections were then incubated with avidin-biotin reagent (1:2) for $30 \mathrm{~min}$, and positive signals were visualized using $0.02 \% 3,3^{\prime}$-diaminobenzidine tetrahydrochloride (DAB) in $50 \mathrm{mM}$ Tris- $\mathrm{HCl}$ ( $\mathrm{pH}$ 7.4) containing $0.02 \% \mathrm{H}_{2} \mathrm{O}_{2}$ followed by nuclear staining with hematoxylin.

\section{Immunofluorescence analysis of $\angle y E C S$ and the $C L$ during the estrous cycle}

The experimental method was modified from that of Maliba et al. (2008). LyECs were grown to confluence, rinsed twice with PBS, and fixed with $4 \%$ paraformaldehyde-PBS solution for $10 \mathrm{~min}$ at room temperature. Following fixation, the cells were washed three times with PBS and blocked with $4 \%$ Block Ace Powder in Tris-buffered saline (TBS) for $15 \mathrm{~min}$ at room temperature. Cells were then incubated with rabbit antimouse-LYVE1 polyclonal antibody (1:100 dilution) for $90 \mathrm{~min}$ at room temperature, rinsed with PBS, and incubated with antirabbit IgG conjugated to Alexa 568 (1:400 dilution) for $60 \mathrm{~min}$ at room temperature. The cells were observed with a confocal microscope (DMI6000B, Leica Microsystems, USA), and the Alexa 568-conjugated antibody was visualized using a $568 \mathrm{~nm}$ argon laser.

The CLs of estrous cycle were stained with LYVE1 antibody as well as the LyECs. After overnight incubation with LYVE1 antibody or goat anti-rabbit IgG as negative control, sections were incubated with anti-rabbit IgG conjugated to Alexa 568 (1:100 dilution) at room temperature for $1 \mathrm{~h}$. The CLs were observed with a confocal microscope, and the Alexa 568-conjugated antibody was visualized using a $568 \mathrm{~nm}$ argon laser. The intensity of LYVE1

Table 1 Primer sequences for the investigated genes.

\begin{tabular}{|c|c|c|c|}
\hline Gene & Primer sequence & Accession no. & $\begin{array}{l}\text { Product } \\
\text { size }(b p)\end{array}$ \\
\hline ISG15 & $\begin{array}{l}\text { FWD: GGT ATG CGA GCT GAA GCA GTT } \\
\text { REV: ACC TCC CTG CTG TCAA GGT }\end{array}$ & NM_174366 & 87 \\
\hline LYVE1 & $\begin{array}{l}\text { FWD: AGG TTG AAG AAG CAC GGA AA } \\
\text { REV: AGG GAT CAT CGG TGG TGA TA }\end{array}$ & NM_205815 & 231 \\
\hline Podoplanin & $\begin{array}{l}\text { FWD: TGG CTA CGG AGC TTT TTC AT } \\
\text { REV: CAC ACC CAG GGT TGT TTT CT }\end{array}$ & $\begin{array}{l}\text { ENSBTAT } \\
00000002341\end{array}$ & 291 \\
\hline VEGFR3 & $\begin{array}{l}\text { FWD: TGA GGA TAA AGG CAG CAT GGA } \\
\text { REV: CCC AGA AAA AGA CAG CGA TGA }\end{array}$ & AF030379 & 66 \\
\hline VEGFC & $\begin{array}{l}\text { FWD: CTC AAG GCC CCA AAC CAG T } \\
\text { REV: CAT CCA GCT TAG ACA TGC ATC G }\end{array}$ & NM_174488 & 71 \\
\hline VEGFD & $\begin{array}{l}\text { FWD: GGA GAA TGC CTT TTG AAC CA } \\
\text { REV: CCA GTC CTC GAA GTG TGT GA }\end{array}$ & $\begin{array}{l}\text { NM_001101043 } \\
\text { XM_590821 }\end{array}$ & 272 \\
\hline$\beta$-actin & $\begin{array}{l}\text { FWD: CCA AGG CCA ACC GTG AGA AGA T } \\
\text { REV: CCA CGT TCC GTG AGG ATC TTC A }\end{array}$ & K00622 & 256 \\
\hline$G A P D H$ & $\begin{array}{l}\text { FWD: CTC TCA AGG GCA TTC TAG GC } \\
\text { REV: TGA CAA AGT GGT CGT TGA GG }\end{array}$ & $\begin{array}{l}\text { ENSBTAT } \\
00000019604\end{array}$ & 120 \\
\hline
\end{tabular}


staining was calculated by the pixel sum/area of the LyECs using the accessory software for this microscope.

\section{Proliferation of LyECS}

LyECs were grown on plates pre-coated with $1 \%$ Vitrogen in complete DMEM/F-12 containing 5\% FBS $\left(1 \times 10^{5}\right.$ cells/well in 24-well plates) for $24 \mathrm{~h}$ at $37^{\circ} \mathrm{C}$. LyECs were then rinsed twice with PBS and incubated for $24 \mathrm{~h}$ in fresh DMEM/F-12 medium containing $0.1 \% \mathrm{FBS}, 1 \mathrm{MNaHCO}_{3}$, gentamicin solution $(50 \mathrm{mg} / \mathrm{l})$, and amphotericin B solution $(2.5 \mathrm{mg} / \mathrm{l})$ supplemented with IFNT $(0.6,6$, or $60 \mathrm{IU} / \mathrm{ml})$. After 24 h, LyECs removed from the dishes were centrifuged at $170 \boldsymbol{g}$ (1000 r.p.m.) for $10 \mathrm{~min}$. After the centrifuge, cell lysate was mixed with the same amount of trypan blue solution. LyEC proliferation was calculated as the number of living LyECs counted by light microscopy (dead cells were stained with trypan blue).

\section{Capillary tube formation on matrigel of LyECS}

LyEC capillary tube formation was evaluated as described previously (Yasuda et al. 2000). Briefly, 48-well plates were coated with $200 \mu \mathrm{l} /$ well of BD Matrigel basement membrane at $4{ }^{\circ} \mathrm{C}$ and then incubated at $37^{\circ} \mathrm{C}$ for at least $1 \mathrm{~h}$ to allow polymerization. LyECs $\left(2 \times 10^{4}\right.$ cells/well $)$ were plated in a final volume of $0.5 \mathrm{ml} /$ well of LyEC culture medium containing IFNT $(60 \mathrm{lU} / \mathrm{ml})$ or recombinant human VEGFC $(100 \mathrm{ng} / \mathrm{ml})$. After incubation for $8 \mathrm{~h}$, tube formation was examined visually and three randomly chosen images taken by inverted microscopy at a magnification of $\times 100$ were imported and the total length of tube formation in each image $(1 \times 1 \mathrm{~mm})$ was analyzed. Data are shown as mean \pm s.E.M.

\section{RNA extraction, cDNA synthesis, and RT quantitative $P C R$}

Total RNA was extracted from CL, PBMC, PMN, LyECs, LECs, and LCs following the protocol of Chomczynski \& Sacchi (1987) using TRIzol reagent, treated with DNase using a commercial kit, and frozen at $-20^{\circ} \mathrm{C}$ in THE RNA Storage Solution. The cDNA was synthesized as described previously (Watanabe et al. 2006). The mRNA expression levels of ISG15, LYVE1, podoplanin, VEGFR3, VEGFC, VEGFD, $\beta$-actin, and GAPDH were quantified by RT quantitative PCR (RT-qPCR) as described previously (Watanabe et al. 2006). RT-qPCRs were performed in duplicate in a final volume of $10 \mu$ l containing $5 \mu \mathrm{l}$ SYBER Green, $2.8 \mu \mathrm{l}$ of $\mathrm{H}_{2} \mathrm{O}, 0.1 \mu \mathrm{l}$ of $50 \mu \mathrm{M}$ forward and reverse primers (Table 1 lists primer sequences and accession numbers), and $2 \mu \mathrm{l}$ cDNA template or water (as nontemplate negative control). RT-qPCR conditions were $10 \mathrm{~min}$ at $95^{\circ} \mathrm{C}$, followed by 40 cycles of $95^{\circ} \mathrm{C}$ for $15 \mathrm{~s}$, and $56^{\circ} \mathrm{C}$ for $30 \mathrm{~s}$ using a LightCycler (Roche Diagnostics Co.). The PCR products were subjected to electrophoresis, and the target bands were cut out and purified using a DNA purification kit (SUPRECTM01). The mRNA expression levels were normalized using $\beta$-actin or GAPDH as an internal standard. Each PCR amplification was sequenced to confirm using an Applied Biosystems $3730 \times$ I DNA analyzer (Applied Biosystems, Foster City, CA, USA).

\section{Western blotting}

The $\mathrm{CL}$ tissue samples were homogenized in lysis buffer containing $25 \mathrm{mM}$ Tris- $\mathrm{HCl}, \mathrm{pH} 7.4,0.3 \mathrm{M}$ sucrose, $2 \mathrm{mM}$ $\mathrm{Na}_{2}$ EDTA, and protease inhibitor cocktail and then filtered with a $70 \mu \mathrm{m}$ filter. The proteins were dissolved in sample buffer (0.5 M Tris- $\mathrm{HCl}, \mathrm{pH} 6.8$, glycerol, $10 \%$ SDS, $0.5 \%$ bromophenol blue) and steamed for $5 \mathrm{~min}$. The entire samples were subjected to electrophoresis on $10 \%$ SDS-PAGE gels for $50 \mathrm{~min}$ at $200 \mathrm{~V}$. The proteins were transferred to PVDF membranes for $2 \mathrm{~h}$ at $60 \mathrm{~V}$. The membranes were blocked with $4 \%$ Block Ace Powder in TBS with $0.5 \%$ Tween-20 for $1 \mathrm{~h}$ at room temperature. The membranes were next incubated with a rabbit anti-mouse-LYVE1 polyclonal antibody (1:500 dilution) and a mouse anti- $\beta$-actin monoclonal clone AC-15 antibody (1:10 000 dilution). The membranes were then washed three times in TBS with $0.5 \%$ Tween-20, incubated with HRP-conjugated anti-rabbit (1:10 000 dilution) or antimouse (1:10 000 dilution) IgG antibodies for $1 \mathrm{~h}$ at room temperature, and washed three times with TBS with $0.5 \%$ Tween-20. The signals were detected using an ECL Western Blotting Detection System. The optical densities of the immunospecific bands were quantified using an $\mathrm{NIH}$ image computer-assisted analysis system.

\section{Statistical analysis}

All data are presented as mean \pm s.E.M. The statistical significance of differences was assessed by one-way ANOVA followed by Fisher's multiple comparison test or Student's t-test. A $P<0.05$ was considered significant.

\section{Declaration of interest}

The authors declare that there is no conflict of interest that could be perceived as prejudicing the impartiality of the research reported.

\section{Funding}

This study was supported by a Grant-in-Aid for Scientific Research of the Japan Society for the Promotion of Science (JSPS) and the Global COE Program, Ministry of Education, Culture, Sports, Science and Technology, Japan.

\section{Acknowledgements}

The authors thank Dr R M Roberts, University of Missouri, Columbia, USA, for bovine IFNT-cDNA (bTP-509A).

\section{References}

Andersen DH 1926 Lymphatic and blood vessels of the ovary of the sow. Contributions to Embryology 88 107-124.

Asselin E, Johnson GA, Spencer TE \& Bazer FW 2001 Monocyte chemotactic protein-1 and -2 messenger ribonucleic acids in the ovine uterus: regulation by pregnancy, progesterone, and interferon-tau. Biology of Reproduction 64 992-1000. (doi:10.1095/biolreprod64.3. 992) 
Baldwin ME, Halford MM, Roufail S, Williams RA, Hibbs ML, Grail D, Kubo H, Stacker SA \& Achen MG 2005 Vascular endothelial growth factor D is dispensable for development of the lymphatic system. Molecular and Cellular Biology 25 2441-2449. (doi:10.1128/MCB.25.6. 2441-2449.2005)

Baluk P, Tammela T, Ator E, Lyubynska N, Achen MG, Hicklin DJ, Jeltsch M, Petrova TV, Pytowski B, Stacker SA et al. 2005 Pathogenesis of persistent lymphatic vessel hyperplasia in chronic airway inflammation. Journal of Clinical Investigation 115 247-257. (doi:10.1172/JCI22037)

Banerji S, Ni J, Wang SX, Clasper S, Su J, Tammi R, Jones M \& Jackson DG 1999 LYVE-1, a new homologue of the CD44 glycoprotein, is a lymphspecific receptor for hyaluronan. Journal of Cell Biology 144 789-801. (doi:10.1083/jcb.144.4.789)

Beindorff N, Nagai K, Shirasuna K, Herzog K, Hoeffmann K, Sasaki M, Bollwein H \& Miyamoto A 2010 Vascular changes in the corpus luteum during early pregnancy in the cow. Journal of Reproduction and Development 56 263-270. (doi:10.1262/jrd.09-150K)

Berisha B, Schams D, Kosmann M, Amselgruber W \& Einspanier R 2000 Expression and tissue concentration of vascular endothelial growth factor, its receptors, and localization in the bovine corpus luteum during estrous cycle and pregnancy. Biology of Reproduction 63 1106-1114. (doi:10.1095/biolreprod63.4.1106)

Bott RC, Ashley RL, Henkes LE, Antoniazzi AQ, Bruemmer JE, Niswender GD, Bazer FW, Spencer TE, Smirnova NP, Anthony RV et al. 2010 Uterine vein infusion of interferon tau (IFNT) extends luteal life span in ewes. Biology of Reproduction 82 725-735. (doi:10.1095/ biolreprod.109.079467)

Brannstrom M, Giesecke L, Moore IC, van den Heuvel CJ \& Robertson SA 1994 Leukocyte subpopulations in the rat corpus luteum during pregnancy and pseudopregnancy. Biology of Reproduction $\mathbf{5 0}$ 1161-1167. (doi:10.1095/biolreprod50.5.1161)

Breiteneder-Geleff S, Soleiman A, Kowalski H, Horvat R, Amann G, Kriehuber E, Diem K, Weninger W, Tschachler E, Alitalo K et al. 1999 Angiosarcomas express mixed endothelial phenotypes of blood and lymphatic capillaries: podoplanin as a specific marker for lymphatic endothelium. American Journal of Pathology 154 385-394. (doi:10. 1016/S0002-9440(10)65285-6)

Chen Y, Green JA, Antoniou E, Ealy AD, Mathialagan N, Walker AM, Avalle MP, Rosenfeld CS, Hearne LB \& Roberts RM 2006 Effect of interferon-tau administration on endometrium of nonpregnant ewes: a comparison with pregnant ewes. Endocrinology 147 2127-2137. (doi:10.1210/en.2005-1310)

Choi Y, Johnson GA, Burghardt RC, Berghman LR, Joyce MM, Taylor KM, Stewart MD, Bazer FW \& Spencer TE 2001 Interferon regulatory factortwo restricts expression of interferon-stimulated genes to the endometrial stroma and glandular epithelium of the ovine uterus. Biology of Reproduction 65 1038-1049. (doi:10.1095/biolreprod65.4.1038)

Chomczynski P \& Sacchi N 1987 Single-step method of RNA isolation by acid guanidinium thiocyanate-phenol-chloroform extraction. Analytical Biochemistry 162 156-159. (doi:10.1016/0003-2697(87) 90021-2)

Cursiefen C, Chen L, Borges LP, Jackson D, Cao J, Radziejewski C, D'Amore PA, Dana MR, Wiegand SJ \& Streilein JW 2004 VEGF-A stimulates lymphangiogenesis and hemangiogenesis in inflammatory neovascularization via macrophage recruitment. Journal of Clinical Investigation 113 1040-1050. (doi:10.1172/JCI20465)

Czeizel E \& Palkovich I 1962 Study of the interual lymphatic vessels of the ovary by experimental lymph stasis. Anatomischer Anzeiger 111 $413-425$.

Farin CE, Imakawa K, Hansen TR, McDonnell JJ, Murphy CN, Farin PW \& Roberts RM 1990 Expression of trophoblastic interferon genes in sheep and cattle. Biology of Reproduction 43 210-218. (doi:10.1095/ biolreprod43.2.210)

Fleming JG, Spencer TE, Safe SH \& Bazer FW 2006 Estrogen regulates transcription of the ovine oxytocin receptor gene through GC-rich SP1 promoter elements. Endocrinology 147 899-911. (doi:10.1210/en. 2005-1120)

Fraser HM, Dickson SE, Lunn SF, Wulff C, Morris KD, Carroll VA \& Bicknell R 2000 Suppression of luteal angiogenesis in the primate after neutralization of vascular endothelial growth factor. Endocrinology 141 995-1000. (doi:10.1210/en.141.3.995)
Gifford CA, Racicot K, Clark DS, Austin KJ, Hansen TR, Lucy MC, Davies CJ \& Ott TL 2007 Regulation of interferon-stimulated genes in peripheral blood leukocytes in pregnant and bred, nonpregnant dairy cows. Journal of Dairy Science 90 274-280. (doi:10.3168/jds.S0022-0302 (07)72628-0)

Girsh E, Wang W, Mamluk R, Arditi F, Friedman A, Milvae RA \& Meidan R 1996 Regulation of endothelin-1 expression in the bovine corpus luteum: elevation by prostaglandin F2 alpha. Endocrinology 137 5191-5196. (doi:10.1210/en.137.12.5191)

Green MP, Spate LD, Bixby JA, Ealy AD \& Roberts RM 2005 A comparison of the anti-luteolytic activities of recombinant ovine interferon-alpha and -tau in sheep. Biology of Reproduction 73 1087-1093. (doi:10.1095/ biolreprod.105.043406)

Han H, Austin KJ, Rempel LA \& Hansen TR 2006 Low blood ISG15 mRNA and progesterone levels are predictive of non-pregnant dairy cows. Journal of Endocrinology 191 505-512. (doi:10.1677/joe.1.07015)

Hansen TR, Austin KJ \& Johnson GA 1997 Transient ubiquitin cross-reactive protein gene expression in the bovine endometrium. Endocrinology 138 5079-5082. (doi:10.1210/en.138.11.5079)

Hansen TR, Austin KJ, Perry DJ, Pru JK, Teixeira MG \& Johnson GA 1999 Mechanism of action of interferon-tau in the uterus during early pregnancy. Journal of Reproduction and Fertility. Supplement $\mathbf{5 4}$ 329-339.

Hansen TR, Henkes LE, Ashley RL, Bott RC, Antoniazzi AQ \& Han H 2010 Endocrine actions of interferon-tau in ruminants. Society of Reproduction and Fertility Supplement 67 325-340. (doi:10.5661/RDR-VII-325)

Imakawa K, Anthony RV, Kazemi M, Marotti KR, Polites HG \& Roberts RM 1987 Interferon-like sequence of ovine trophoblast protein secreted by embryonic trophectoderm. Nature 330 377-379. (doi:10.1038/ 330377a0)

Iwata C, Kano MR, Komuro A, Oka M, Kiyono K, Johansson E, Morishita Y, Yashiro M, Hirakawa K, Kaminishi M et al. 2007 Inhibition of cyclooxygenase-2 suppresses lymph node metastasis via reduction of lymphangiogenesis. Cancer Research 67 10181-10189. (doi:10.1158/ 0008-5472.CAN-07-2366)

Jiemtaweeboon S, Shirasuna K, Nitta A, Kobayashi A, Schuberth HJ, Shimizu T \& Miyamoto A 2011 Evidence that polymorphonuclear neutrophils infiltrate into the developing corpus luteum and promote angiogenesis with interleukin-8 in the cow. Reproductive Biology and Endocrinology 9 79. (doi:10.1186/1477-7827-9-79)

Johnson GA, Austin KJ, Van Kirk EA \& Hansen TR 1998 Pregnancy and interferon-tau induce conjugation of bovine ubiquitin cross-reactive protein to cytosolic uterine proteins. Biology of Reproduction $\mathbf{5 8}$ 898-904. (doi:10.1095/biolreprod58.4.898)

Johnson GA, Spencer TE, Hansen TR, Austin KJ, Burghardt RC \& Bazer FW 1999 Expression of the interferon tau inducible ubiquitin cross-reactive protein in the ovine uterus. Biology of Reproduction 61 312-318. (doi:10.1095/biolreprod61.1.312)

Joukov V, Sorsa T, Kumar V, Jeltsch M, Claesson-Welsh L, Cao Y, Saksela O, Kalkkinen N \& Alitalo K 1997 Proteolytic processing regulates receptor specificity and activity of VEGFC. EMBO Journal 16 3898-3911. (doi:10. 1093/emboj/16.13.3898)

Karkkainen MJ, Haiko P, Sainio K, Partanen J, Taipale J, Petrova TV, Jeltsch M, Jackson DG, Talikka M, Rauvala H et al. 2004 Vascular endothelial growth factor $\mathrm{C}$ is required for sprouting of the first lymphatic vessels from embryonic veins. Nature Immunology 5 74-80. (doi:10. 1038/ni1013)

Klipper E, Gilboa T, Levy N, Kisliouk T, Spanel-Borowski K \& Meidan R 2004 Characterization of endothelin-1 and nitric oxide generating systems in corpus luteum-derived endothelial cells. Reproduction $\mathbf{1 2 8}$ 463-473. (doi:10.1530/rep.1.00271)

Kubo H, Cao R, Brakenhielm E, Makinen T, Cao Y \& Alitalo K 2002 Blockade of vascular endothelial growth factor receptor-3 signaling inhibits fibroblast growth factor-2-induced lymphangiogenesis in mouse cornea. PNAS 99 8868-8873. (doi:10.1073/pnas.062040199)

Leak LV, Yu ZX, Jones M \& Ferrans VJ 1999 Characterization of a transformed ovine lymphatic endothelial cell line. Microcirculation 6 63-73. (doi:10.1111/j.1549-8719.1999.tb00088.x)

Lei ZM, Chegini N \& Rao CV 1991 Quantitative cell composition of human and bovine corpora lutea from various reproductive states. Biology of Reproduction 44 1148-1156. (doi:10.1095/biolreprod44.6. 1148) 
Li J \& Roberts RM 1994 Interferon-tau and interferon-alpha interact with the same receptors in bovine endometrium. Use of a readily iodinatable form of recombinant interferon-tau for binding studies. Journal of Biological Chemistry 269 13544-13550.

Maliba R, Brkovic A, Neagoe PE, Villeneuve LR \& Sirois MG 2008 Angiopoietin-mediated endothelial P-selectin translocation: cell signaling mechanisms. Journal of Leukocyte Biology 83 352-360. (doi:10. 1189/jlb.0107056)

Meyer MD, Hansen PJ, Thatcher WW, Drost M, Badinga L, Roberts RM, Li J, Ott TL \& Bazer FW 1995 Extension of corpus luteum lifespan and reduction of uterine secretion of prostaglandin F2 alpha of cows in response to recombinant interferon-tau. Journal of Dairy Science $\mathbf{7 8}$ 1921-1931. (doi:10.3168/jds.S0022-0302(95)76817-5)

Millauer B, Wizigmann-Voos S, Schnurch H, Martinez R, Moller NP, Risau W \& Ullrich A 1993 High affinity VEGF binding and developmental expression suggest Flk-1 as a major regulator of vasculogenesis and angiogenesis. Cell 72 835-846. (doi:10.1016/0092-8674(93) 90573-9)

Miyamoto A \& Schams D 1991 Oxytocin stimulates progesterone release from microdialyzed bovine corpus luteum in vitro. Biology of Reproduction 44 1163-1170. (doi:10.1095/biolreprod44.6.1163)

Miyamoto A, Shirasuna K \& Sasahara K 2009 Local regulation of corpus luteum development and regression in the cow: impact of angiogenic and vasoactive factors. Domestic Animal Endocrinology 37 159-169. (doi:10.1016/j.domaniend.2009.04.005)

Miyamoto A, Shirasuna K, Shimizu S, Bollwein H \& Schams D 2010 Regulation of corpus luteum development and maintenance: specific roles of angiogenesis and action of prostaglandin F2 alpha. Society of Reproduction and Fertility Supplement 67 289-304.

Morris B \& Sass M 1966 The formation of lymph in the ovary. Proceedings of the Royal Society of London. Series B, Biological Sciences 164 577-591. (doi:10.1098/rspb.1966.0049)

Murata K 1976 Fine distribution of lympha vessels within the ovaries. Journal of Tokyo Medical College 34 425-437.

Nagaoka K, Sakai A, Nojima H, Suda Y, Yokomizo Y, Imakawa K, Sakai S \& Christenson RK 2003 A chemokine, interferon (IFN)-gamma-inducible protein $10 \mathrm{kDa}$, is stimulated by IFN-tau and recruits immune cells in the ovine endometrium. Biology of Reproduction 68 1413-1421. (doi:10. 1095/biolreprod.102.008912)

Nguyen VP, Chen SH, Trinh J, Kim H, Coomber BL \& Dumont DJ 2007 Differential response of lymphatic, venous and arterial endothelial cells to angiopoietin-1 and angiopoietin-2. BMC Cell Biology 8 10. (doi:10. 1186/1471-2121-8-10)

Oliveira JF, Henkes LE, Ashley RL, Purcell SH, Smirnova NP, Veeramachaneni DN, Anthony RV \& Hansen TR 2008 Expression of interferon (IFN)-stimulated genes in extrauterine tissues during early pregnancy in sheep is the consequence of endocrine IFN-tau release from the uterine vein. Endocrinology 149 1252-1259. (doi:10.1210/en. 2007-0863)

O'Shea JD, Rodgers RJ \& D'Occhio MJ 1989 Cellular composition of the cyclic corpus luteum of the cow. Journal of Reproduction and Fertility 85 483-487. (doi:10.1530/jrf.0.0850483)

Otsuki Y, Magari S \& Sugimoto O 1987 Fine structure and morphometric analysis of lymphatic capillaries in the developing corpus luteum of the rabbit. Lymphology 20 64-72.

Penny LA 2000 Monocyte chemoattractant protein 1 in luteolysis. Reviews of Reproduction 5 63-66. (doi:10.1530/ror.0.0050063)

Podgrabinska S, Braun P, Velasco P, Kloos B, Pepper MS \& Skobe M 2002 Molecular characterization of lymphatic endothelial cells. PNAS 99 16069-16074. (doi:10.1073/pnas.242401399)

Prevo R, Banerji S, Ferguson DJ, Clasper S \& Jackson DG 2001 Mouse LYVE-1 is an endocytic receptor for hyaluronan in lymphatic endothelium. Journal of Biological Chemistry 276 19420-19430. (doi:10. 1074/jbc.M011004200)

Reibiger I \& Spanel-Borowski K 2000 Difference in localization of eosinophils and mast cells in the bovine ovary. Journal of Reproduction and Fertility 118 243-249. (doi:10.1530/reprod/118.2.243)

Roberts RM, Cross JC \& Leaman DW 1992 Interferons as hormones of pregnancy. Endocrine Reviews 13 432-452. (doi:10.1210/edrv-13-3-432)

Roberts RM, Xie S \& Mathialagan N 1996 Maternal recognition of pregnancy. Biology of Reproduction 54 294-302. (doi:10.1095/biolreprod54.2.294)
Robinson RS, Woad KJ, Hammond AJ, Laird M, Hunter MG \& Mann GE 2009 Angiogenesis and vascular function in the ovary. Reproduction 138 869-881. (doi:10.1530/REP-09-0283)

Schams D \& Berisha B 2004 Regulation of corpus luteum function in cattle an overview. Reproduction in Domestic Animals 39 241-251. (doi:10. 1111/j.1439-0531.2004.00509.x)

Schams D, Stefanie S, Heinrich HDM \& Bajram B 2009 Expression of lymphangiogenic factors in bovine corpus luteum during estrous cycle, pregnancy, and induced luteolysis. Biology of Reproduction $\mathbf{8 1}$ (Meeting Abstracts) 514

Shalaby F, Rossant J, Yamaguchi TP, Gertsenstein M, Wu XF, Breitman ML \& Schuh AC 1995 Failure of blood-island formation and vasculogenesis in Flk-1-deficient mice. Nature 376 62-66. (doi:10.1038/376062a0)

Shirasuna K, Watanabe S, Asahi T, Wijayagunawardane MP, Sasahara K, Jiang C, Matsui M, Sasaki M, Shimizu T, Davis JS et al. 2008 Prostaglandin F2alpha increases endothelial nitric oxide synthase in the periphery of the bovine corpus luteum: the possible regulation of blood flow at an early stage of luteolysis. Reproduction 135 527-539. (doi:10.1530/REP-07-0496)

Shirasuna K, Asahi T, Sasaki M, Shimizu T \& Miyamoto A 2009 Distribution of arteriolovenous vessels, capillaries and eNOS expression in the bovine corpus luteum during the estrous cycle: a possible implication of different sensitivity by luteal phase to $\operatorname{PGF}(2$ alpha $)$ in the increase of luteal blood flow. Journal of Reproduction and Development $\mathbf{5 6}$ 124-130. (doi:10.1262/jrd.09-106O)

Skarzynski DJ, Miyamoto Y \& Okuda K 2000 Production of prostaglandin $\mathrm{F}$ (2alpha) by cultured bovine endometrial cells in response to tumor necrosis factor alpha: cell type specificity and intracellular mechanisms. Biology of Reproduction 62 1116-1120. (doi:10.1095/biolreprod62.5. 1116)

Spanel-Borowski K 1991 Diversity of ultrastructure in different phenotypes of cultured microvessel endothelial cells isolated from bovine corpus luteum. Cell and Tissue Research 266 37-49. (doi:10.1007/ BF00678709)

Spencer TE \& Bazer FW 1996 Ovine interferon tau suppresses transcription of the estrogen receptor and oxytocin receptor genes in the ovine endometrium. Endocrinology 137 1144-1147. (doi:10.1210/en.137.3. 1144)

Spencer TE, Becker WC, George P, Mirando MA, Ogle TF \& Bazer FW 1995 Ovine interferon-tau inhibits estrogen receptor up-regulation and estrogen-induced luteolysis in cyclic ewes. Endocrinology 136 4932-4944. (doi:10.1210/en.136.11.4932)

Spencer TE, Stagg AG, Ott TL, Johnson GA, Ramsey WS \& Bazer FW 1999 Differential effects of intrauterine and subcutaneous administration of recombinant ovine interferon tau on the endometrium of cyclic ewes. Biology of Reproduction 61 464-470. (doi:10.1095/biolreprod61.2.464)

Spencer TE, Burghardt RC, Johnson GA \& Bazer FW 2004 Conceptus signals for establishment and maintenance of pregnancy. Animal Reproduction Science 82-83 537-550. (doi:10.1016/j.anireprosci. 2004.04.014)

Staggs KL, Austin KJ, Johnson GA, Teixeira MG, Talbott CT, Dooley VA \& Hansen TR 1998 Complex induction of bovine uterine proteins by interferon-tau. Biology of Reproduction 59 293-297. (doi:10.1095/ biolreprod59.2.293)

Standaert FE, Zamora CS \& Chew BP 1991 Quantitative and qualitative changes in blood leukocytes in the porcine ovary. American Journal of Reproductive Immunology 25 163-168.

Teixeira MG, Austin KJ, Perry DJ, Dooley VD, Johnson GA, Francis BR \& Hansen TR 1997 Bovine granulocyte chemotactic protein-2 is secreted by the endometrium in response to interferon-tau (IFN-tau). Endocrine 6 31-37. (doi:10.1007/BF02738799)

Wang Y \& Oliver G 2010 Current views on the function of the lymphatic vasculature in health and disease. Genes and Development 24 2115-2126. (doi:10.1101/gad.1955910)

Watanabe S, Shirasuna K, Matsui M, Yamamoto D, Berisha B, Schams D \& Miyamoto A 2006 Effect of intraluteal injection of endothelin type A receptor antagonist on PGF2alpha-induced luteolysis in the cow. Journal of Reproduction and Development 52 551-559. (doi:10.1262/ jrd.18018)

Wilting J, Eichmann A \& Christ B 1997 Expression of the avian VEGF receptor homologues Quek1 and Quek2 in blood-vascular and 
lymphatic endothelial and non-endothelial cells during quail embryonic development. Cell and Tissue Research 288 207-223. (doi:10.1007/ s004410050807)

Woad KJ, Hammond AJ, Hunter M, Mann GE, Hunter MG \& Robinson RS 2009 FGF2 is crucial for the development of bovine luteal endothelial networks in vitro. Reproduction 138 581-588. (doi:10.1530/REP-090030)

Wulff C, Wilson H, Rudge JS, Wiegand SJ, Lunn SF \& Fraser HM 2001 Luteal angiogenesis: prevention and intervention by treatment with vascular endothelial growth factor trap(A40). Journal of Clinical Endocrinology and Metabolism 86 3377-3386. (doi:10.1210/jc.86.7. 3377)

Xu F \& Stouffer RL 2009a Existence of the lymphatic system in the primate corpus luteum. Lymphatic Research and Biology 7 159-168. (doi:10. 1089//rb.2009.0009)

Xu F \& Stouffer RL 2009b Local delivery of an anti-lymphangiogenic agent supresses ovulation in the monkey. Biology of Reproduction $\mathbf{8 1}$ ABSTRACT 516. (doi:10.1095/biolreprod.108.074732)

Yamada Y, Nezu J, Shimane M \& Hirata Y 1997 Molecular cloning of a novel vascular endothelial growth factor, VEGFD. Genomics 42 483-488. (doi:10.1006/geno.1997.4774)

Yamashita H, Kamada D, Shirasuna K, Matsui M, Shimizu T, Kida K, Berisha B, Schams D \& Miyamoto A 2008 Effect of local neutralization of basic fibroblast growth factor or vascular endothelial growth factor by a specific antibody on the development of the corpus luteum in the cow. Molecular Reproduction and Development 75 1449-1456. (doi:10.1002/mrd.20878)

Yang L, Wang XL, Wan PC, Zhang LY, Wu Y, Tang DW \& Zeng SM 2010 Upregulation of expression of interferon-stimulated gene 15 in the bovine corpus luteum during early pregnancy. Journal of Dairy Science $\mathbf{9 3}$ 1000-1011. (doi:10.3168/jds.2009-2529)
Yasuda M, Shimizu S, Tokuyama S, Watanabe T, Kiuchi Y \& Yamamoto T 2000 A novel effect of polymorphonuclear leukocytes in the facilitation of angiogenesis. Life Sciences 66 2113-2121. (doi:10.1016/S00243205(00)00537-3)

Zarco L, Stabenfeldt GH, Basu S, Bradford GE \& Kindahl H 1988a Modification of prostaglandin F-2 alpha synthesis and release in the ewe during the initial establishment of pregnancy. Journal of Reproduction and Fertility 83 527-536. (doi:10.1530/jrf.0.0830527)

Zarco L, Stabenfeldt GH, Quirke JF, Kindahl H \& Bradford GE $1988 b$ Release of prostaglandin F-2 alpha and the timing of events associated with luteolysis in ewes with oestrous cycles of different lengths. Journal of Reproduction and Fertility 83 517-526. (doi:10.1530/jrf.0. 0830517)

Zeng Y, Opeskin K, Goad J \& Williams ED 2006 Tumor-induced activation of lymphatic endothelial cells via vascular endothelial growth factor receptor-2 is critical for prostate cancer lymphatic metastasis. Cancer Research 66 9566-9575. (doi:10.1158/0008-5472. CAN-06-1488)

Zheng J, Redmer DA \& Reynolds LP 1993 Vascular development and heparin-binding growth factors in the bovine corpus luteum at several stages of the estrous cycle. Biology of Reproduction 49 1177-1189. (doi:10.1095/biolreprod49.6.1177)

Received 8 May 2011

First decision 20 June 2011

Revised manuscript received 4 September 2011

Accepted 20 September 2011 